\title{
Tianxia-Country-Family, Huaxia-centrism, Unity: State Concept of Traditional Chinese
}

\author{
Lei Wang \\ School of Marxism Studies \\ Nanjing Normal University \\ 210023, Nanjing, China \\ 14200@njnu.edu.cn
}

\begin{abstract}
This paper argues that the traditional China is a "state", and has its own specific national concept. There are three important state concepts in traditional Chinese heart. One of which is Tianxia-Country-Family, and the second is Huaxiacentrism, with the two aspects of geographical superiority and Chinese cultural superiority, Unity of cosmological and political order is the third, including of the unification of China, centralization \& the monarch supreme and ideological unity. Whether positive or negative, these traditional concepts of state from Qin to late Qing dynasty constitute the experiences premise of political actions and thoughts creating for modern Chinese.
\end{abstract}

Keywords-State concept; traditional Chinese; TianxiaCountry-Family; Huaxia-centrism; Unity

\section{INTRODUCTION}

The victory of Xinhai Revolution and the establishment of Nanjing Provisional Government of the Republic of China that ended two thousand years of dynastic autocracy, symbolized the "beginning" (Chen Duxiu) to build a modern state for Chinese. [1] So "Traditional China" and "Traditional Chinese" in this paper are often seen as synonymous with "Ancient China" and "Ancient Chinese" that mainly refer to this period of time from Qin dynasty that China unified in BC221 to the Republic of China established in 1911. As the endless circles about whether China is a traditional "state", For example, G. W. Hegel believed that the ancient China "is entirely a state" [2], Liang Shuming thought that traditional Chinese lack the proper function of the State, lack of international antagonism, extreme lack of national ideas, so in his idea, traditional China was "Unlike a state". [3] In this regard, we do not intend to participate in the argument. In this paper, we argue that the traditional China is a "state" and traditional Chinese have own specific state concept.

\section{TIANXIA-COUNTRY-FAMILY}

The concept and practice of nation-state is the natural product and inevitable result of the development of production mode of capitalist, the typical nation-state originated in the late middle Ages in Western Europe. The reason for this is closely related to the traditional view of Western Europe, which regards the polis as an ideal political community in the political life. For example, in the Chapter I of the Theory Of The Household of the politics, Aristotle (384-322 BC) said that,

Sponsored by A Project Funded by the Priority Academic Program Development of Jiangsu Higher Education Institutions (PAPD), and Scientific Research Start Project for Introducing Talents of Nanjing Normal University: on the Growth History of Nation-state Concept in modern China (1911-1931).
"Every polis (or state) is a species of association", " all associations aim at some good; and we may also hold that the particular association which is the most sovereign of all, and includes all the rest, will pursue this aim most, and will thus be directed to the most sovereign of all goods. This most sovereign and inclusive association is the polis, as it is called, or the political association. "And more important is, in Aristotle's words," All associations have ends: the political association has the highest."

But different from the West tradition, which taking the Polis (State) as a "political association" and the pursuit of it regarded as the most sublime, there is no "political association" sense in traditional Chinese state concept. By contrast, there is a cultural, political and economy sense of Tianxia concept with traditional Chinese. As Liang Qichao said, "Ancient Chinese philosophers talk about politics; hundreds of them have the same sence that begin Tianxia as an object". [4]"Selfcultivation, family harmony, country management and Tianxia peace" (修身、 $\square$ 家、治国、平天下) becomes the highest good that traditional Chinese people pursued, just like one of the "Four Books" in Confucianism, Great Learning say:

"The ancients, who wished to illustrate illustrious virtue throughout the world, first ordered well their own States. Wishing to order well their States, they first regulated their families. Wishing to regulate their families, they first cultivated their persons. Wishing to cultivate their persons, they first rectified their hearts. Wishing to rectify their hearts, they first sought to be sincere in their thoughts. Wishing to be sincere in their thoughts, they first extended to the utmost of their knowledge. Such extension of knowledge lay in the investigation of things. Things being investigated, knowledge became complete. Their knowledge being complete, their thoughts were sincere. Their thoughts being sincere, their hearts were then rectified. Their hearts being rectified, their persons were cultivated. Their persons being cultivated, their families were regulated. Their families being regulated, their States were rightly governed. Their States being rightly governed, the entire world was at peace."(Reference resources: Great Learning from Wikipedia )

In traditional China, Tianxia was at the top of political and social structure, and then was feudatory's Country and Dafu's Family. A sentence of Mencius, 372-289BC, a Chinese philosopher who is the most famous Confucian after Confucius 
himself is highly summarized of the traditional Chinese state concept. "People have common saying, we all say: 'TianxiaCountry-Family', the foundation of 'Tianxia' is country, the foundation of country is family, and the foundation of family is the body". Zhao Qi (108-201), the author of Commentaries on Mencius, once explained: "Place ruled by the Emperor could be called Tianxia, the Emperor own Tianxia." Zhao Tingyang also explains that Theory of Tinaxia is important, because it takes the 'world' as a political unit, a maximum and the highest political unit. At the same time, it has become analysis unit of thinking about all life problems, and also the biggest scene or interprets condition.

So-called, "Country" of "'Tianxia-Country-Family', Zhao Qi further explained, the emperor who own the 'Tianxia' be called 'Tianxia', feudatory that own the country be called 'Country'. However, who own the country cannot be called 'Tianxia', who own the 'Tianxia' may be called country, so the feudatory can be called feudal country, the emperor can be called Kingdom.(國家文从或, 又从國, $\square$ 其或之也, 故國之 也)As for the family, then from the emperor to the common people all can be called."[5]

In fact, there are very big difference between traditional Chinese concept “Guojia 國家” and modern discourse "state".

“Guojia 國家” in traditional concept has two meanings "Country" and "Family". On the "State" itself, also has two meanings, "feudal country" ruled by Princes and "Kingdom" ruled by King. However, this situation has been a significant change that named "feudal country" gradually disappears, replaced by a county administrative government office, since Qin Dynasty complete reunification of China, at the same time, the emperor's Tianxia and the feudatory's Country has gradually been replaced by central and local relations appellation. But the state concept that area ruled by emperor named "Tianxia" has been not changed too much. Moreover, by contrary, with the deepening of the centralized system, this concept that being the "Tianxia" with one family and one name own, not decreased, but increased. As a result, "Owner in eyes of Chinese, the close area is family, the far is Tianxia, and besides are ignored mostly", Liang Qichao once said.

In a word, the traditional Chinese concepts of "Guojia" are difference from the western state concept in the sense of political association. For example, Liang Qichao pointed out that, Chinese always did not recognize the state as the highest human groups from its own culture created. Chinese political theory often takes the whole human being as its object, so the purpose is the world, but the country as the same as the family, become the stages of the "Tianxia". For this state concept of Tianxia-Country-Family, Whether Liang Qichao, Chen Duxiu, or Zeng Qi, has a clear and definite understanding. Liang believed that the Chinese people "known to have the Tianxia but do not know the State", "Alas, we Chinese people have no state concept." Chen also pointed out that, "Our Chinese nation, that closing-door from ancient, dominating East Asia, have no concept of the state, but Tianxia concept, before developed the trade treaty among Europe, the US and Japan", and "European nation, states side by side since ancient times, have deeper concept of state." [6]Zeng Qi is also holding this view.
Thus, giving the "Tianxia" disenchantment had become the first effort direction for modern Chinese advanced elements. At the same time, the intellectuals thinking of the "Tianxia", the "World", and the "state", As well as an effort to turn the "Tianxia" concept into the "world" and increase the "State" in the modern sense, constitute an important part of Chinese modern nation-state concept generated.

\section{HUAXIA-CENTRISM}

Traditional Chinese state concept of Tianxia-CountryFamily is not only regarding China as the "Tianxia", but as the center of "Tianxia", As Jin Guantao said, "All the world is Tianxia by the center of Huaxia, rather than a collection of nation-states." [7] We may sum up it as the state concept of "Huaxia-centrism", embodied in two aspects:

\section{A. China is in the center of the "the world"}

One of which is geographical superiority which the Huaxia and Han rulers thought that they were living in the center of the "the world". This sense of superiority can be seen from China, Zhonghua which was used in the name of the country by the ancients. For example, famous scholar Shi Jie, living in Song Dynasty pointed out that, "The heaven is at top, the earth at bottom, habituating the center of the heaven and earth is China, occupying the corners are barbarians. Different from barbarians living outside of the heaven and earth, China is living inside." In the late 16th century, Italian Jesuit Matteo Ricci also pointed out that "today we usually call this country Ciumquo or Ciumhoa, the first word indicates kingdom, another word for garden. Word on together is translated as 'central'. I heard that the reason of calling this name is because Chinese believed that sky is round and earth is square, and China is located in the Central Plains." [8] It is said that in order to cater to this kind of psychology of Chinese people's, Matteo Ricci specially drawn a map that marked in Chinese, and try to make the China much occupies a central position. In fact, until 12 years of Qianlong, "Dynasty literature textual research "was emphasized, "The earth is 72000 Chinese mile long form west to east, such as north to south. China is located in the center, surrounded by the sea.

According to the observation of Matteo Ricci, in the traditional Chinese concept, China "vast territory is actually on the border with the edge of the universe", and in addition to the territory outside the vast, "country great, political system and academic reputation concerned", all other nations are "as is a savage, and as animals with no rational ", in addition to China, "the world no king of the other party, dynasty or culture is worth boast". The reason why there is such a view, because in the eyes of Chinese, China is a country with culture, and it is a country with superiority culture.

\section{B. Chinese cultural is superiority}

The other aspect of Huaxia-centrism is Chinese cultural superiority, in other words "Distinction between Chinese and non-Chinese cultures"( $\square$ 夷之辨). According to Ricci observed, "Just as great nation, political system and in terms of academic reputation", except Huaxia, other people have been "regarded as barbarians and animals with no rational," and 
outside China, "there is no other king, the other dynasties or culture is to boast about." Most important thing is that in the consciousness of the Huaxia and Han rulers, Only Chinese culture is the most outstanding, others are either uneducated or only inferior culture. "Commending Zhonghua, belittling barbarians" becomes the basic concept of the rulers of Central Plains in traditional China. Such as Salt-iron Theory, a book Western Han Dynasty, intermediate stage important work, written by Huan Kuan, clearly pointed out: "China is the center of the world, the total of the Magi, the collection of righteousness, the creation of property."

From Liang Shuming's viewpoint, Traditional Chinese have no modern state concept; they are responsible for the protection of neither country nor nationality, but culture. Thus, the traditional "China" is often regarded as a cultural association. Liang Qichao also pointed that "Chinese unification since ancient times, which line up in a circle were small barbarians with no cultural relics, no government, there were cannot be no country, We Chinese people were always not equal to the status of these countries, so for thousands of years, our country is often in independent status, we call for Yuyu, refers to the Tianxia, and not for the country."

\section{A brief review}

Objectively speaking, in the years since the Qin Dynasty, Chinese civilization is indeed a long-term resident in the forefront of the development of the world civilization. As someone says, "From 3 Century to 13 Century, Chinese has maintained a Western unmatched level of scientific knowledge...China's inventions and discoveries are often more than the same period of Europe, especially before 15 Century." According to later studies, before 16 Century, the impact of major scientific and technological inventions of human life, half of them were Chinese people's invention. Until the end of 18 Century, China's economy is still the largest in the world. Very remarkable is that the ancient Chinese people not only created a high degree of material civilization, but also created a brilliant spiritual civilization and institutional civilization, for example, imperial examination system and so on.

It is these splendid civilization and culture created by ancestors that caused the Chinese people cultural selfconfidence and sense of superiority of civilization along two thousand years. At the same time, this confidence and superior further encouraged the Chinese concept of "Huaxia-centrism", which embarked on the extreme of arbitrariness and overweening pride. Until the late Qing Dynasty, this arrogant mentality still appears. Feng Guifen, a strong contributor to the philosophy of the Self-Strengthening Movement undertaken in the late 19th century, once pointed out that, within the world, only China does not need the help of other country in terms of daily demand. Considering the size of the country, climate, geography, products, all rank first in the Earth. This concept constitutes a general mentality of most scholars in late Qing Dynasty.

\section{UNITY OF COSMOLOGICAL AND POLITICAL ORDER}

"Unity of cosmological and political order "(大一 $\square$ ) is an important part of Chinese traditional political culture, but also important keywords to understand and sort out traditional Chinese state concept. This term was first seen in The Gongyang Zhuan (公羊 $\square$ ) which is a commentary on the Spring and Autumn Annals, and is thus one of the classic books of ancient Chinese.

In the spring and autumn and the Warring States period, the old social system and the ruling order have been destroyed, but the new system and the order have not been established, people in China have been suffering from the war, and have a great desire for unity. Emperor Qin Shihuang established a unified social, political system and centralized government by force had laid the foundation of China's two thousand years of autocratic monarchy. After Qin Shi Huang completed "Great Unification" in practice and institutional, Dong Zhongshu further deepen and developed this ideal in terms of ideology, "Unity of cosmological and political order in the Spring and Autumn Annals, is a classic rule no matter heaven and earth, ancient and modern." In summary, state concept of Unity which developed from Dong and improved by later generations gradually, has profound impact on the whole traditional Chinese. In addition to the above said the "China-centrism", also include the following components at least:

\section{A. Unification of China}

The first theme is the unification of China. In 221 BC, Qin Shi Huang conquered all other Warring States, united China and established a centralized regime by force. Over the next 900 years, it successively appeared multiple "unified" dynasties, for example, the Western Han Dynasty, the Eastern Han Dynasty, the Western Jin Dynasty, Sui Dynasty, Tang Dynasty, Yuan Dynasty, Ming and Qing Dynasty. According to the research findings by Professor Ge Jianxiong, a former Fudan University Librarian, from the length of time, "division, partition is the main, unified is very short" in the history of China, [9] but in my opinion, people's desire of ending the war and unifying the country is consistently. One of most famous Chinese poem written by Lu You, a prominent poet of China's Southern Song Dynasty, expressed this desire vividly. To My Son: All turns to dust in my dying eyes, only hatred is that a unified land is not seen. When the day of the emperor's troops sweeping the North comes, you must not forget to tell me at my tombstone. Particularly important is, that often in the country's unrest, there were always some regimes trying to unify the country. In the history of China, whether it is unified or divided, mostly the result of the comprehensive function of various conditions, not all dynasties had completed the unification of China, but the trend of China will come out of division into unity is an objective law that independent of man's will.

\section{B. Centralization \& the Monarch supreme}

The second theme is centralization \& the monarch supreme, which are two important contents of the traditional China state concept of "unified", that involving the relationship between central and local, monarchical and Robinson rights.

First, main manifestation of understanding of centralization is the debate about two kind of national structure form of "feudal" and "county". In simple terms, the essence of the feudal system is decentralization, county system is 
centralization. Both of the feudal system and the county system in China have a long history, which can be traced back to the Shang Dynasty and the Western Zhou Dynasty, but the mainstream of Chinese history is centralization of power.

Second, the main manifestation of understanding of the monarch supreme is the relationship between monarchical authority and the minister, but the mainstream is monarchical supremacy, which to the only and mandate of heaven as the first performance, and the second performance is the hereditary system of the emperor passed. Specifically, pass the throne to the eldest son, rather than the son of a talent. The third is the status hierarchy, people shall not trespass order that the emperor is sacred. And the forth is the ritual naming hierarchy, Power should be consistent with the level, such as only the emperor has the power to use the tripod to worship. In short, whether from practical viewpoint or philosophy, it is an era of completing centralization system and heyday of absolute monarchy since the Qin Dynasty to the Qing Dynasty Emperor Qianlong Dynasty in China. Since Qianlong, the traditional dynasty gradually embarked on a downhill, and never had seen radiant.

\section{Ideological Unity}

The third theme is ideological unity. The state concept of unity of cosmological and political order calls for an implementation of centralized control of ideology and culture. After the effort of Tung Chung-shu, that is traditionally associated with the promotion of Confucianism as the official ideology of the Chinese imperial state, defending the orthodox ideology of Confucianism becomes customary practice for rulers. To provide institutional guarantee for the official status of Confucianism, Han dynasty carried out a series of measures, such as the education of Confucianism, Confucian scholar of officials, Confucianism justice and so on. After the Han Dynasty, in order to unify their thinking with Confucianism, each dynasty not only held Confucius memorial ceremony, sacred Confucius and other founders of Confucianism, Confucianism will also be taken as an important examination contents to select talents. Confucian Temple which was originally a private Temple of the disciples of Confucius, then gradually became the country's official temple for the kings and the civil and military ministers to worship.

The implementation of Confucianism domination, that unifying people's thought within the scope of the Confucian education, ensured the long-term and effective rule of the autocratic monarchy, on the one hand; On the other hand also suppressed the survival of other thoughts. At the same time, Confucianism as the exam content of talent selection mechanism finally evolved into a dogmatic rigidity of eightpart essays, and gradually became a kind of word game. As a result, it has brought great negative effects for the development of Chinese ideology and culture.

\section{CONCLUSION}

K. C. Hsiao, best known for his contributions to Chinese political science and history, pointed out that "the concept of Unity of Tianxia, is deeply rooted in the hearts of the people after the Qin and Han dynasties" in his famous book History of Chinese Political Thought.[10] We strongly agree with his point. With the keywords of "tianxia", "center" and "unity", traditional Chinese state concept, constitutes an important historical heritage of the conception growth of the modern Chinese nation-state idea. For this, we should use the dialectical method to critical summary, both see the traditional concept of the nation State Concept on the positive side of growth, such as the concept and system itself of unification, centralization of China, is the important constituent elements of nation-state, also the negative side, such as advocated "Distinction between Chinese and non-Chinese cultures", ideological unification, and so on, had created serious obstacle to the growth of nation-state concept. Of course, whether positive or negative, the traditional Chinese concepts of state from Qin to the late Qing dynasty constitute the experiences premise of political actions and thoughts creating for modern Chinese.

\section{ACKNOWLEDGMENTS}

This paper is modification on the basis of my $\mathrm{PhD}$ thesis, thanks to my PhD supervisor, Professor Yue Wang, Nanjing Normal University for careful guidance, while expressing my sincere gratitude to Professor Zhengke Zhang of Anhui Normal University.

\section{REFERENCES}

[1] Chen Duxiu. Anti-Japanese War and the founding of modern state, political ten-day review, vol. 1( 9 ). April 25, 1938.

[2] Hegel. The philosophy of history, Shanghai bookstore publishing house, 2006, p. 148.

[3] Liang shu-ming. The Chinese cultural essence, Shanghai people's publishing house, 2011.pp. 152-159.

[4] Liang qichao. The pre-Qin political thought, Orient press, 2012, p. 212.

[5] Zhao Qi. The imperial family Mencius appearance, Shandong pictorial publishing house, 2004, p. 192.

[6] Chen Duxiu. We should not be patriotic? , the weekly review, no. 25, June 8, 1919.

[7] Jin Guantao, Liu qingfeng. The study of the history of ideas: the formation of modern China's most important political terms, Beijing: Law press, 2009, p. 231

[8] Matteo Ricci, Ginnie Cabinet. Matteo Ricci Chinese reading notes, Beijing: Zhong Hua press, 2010, p. 6.

[9] Ge Jianxiong. Unification and Division: Apocalypse of the History of China, the Commercial Press, 2013, p.83.

[10] K. C. Hsiao. History of Chinese Political Thought, Commercial Press, 2011, p.663. 